\title{
The Genesis Mechanism of Enriched Lithospheric Mantle in Jiaodong Peninsula: Evidence from Inherited Zircon Ages of the Lamprophyres
}

WANG DONG ${ }^{1,2}$, Li HONGYAN ${ }^{1 *}$, DENG JUN ${ }^{2}$, Yu HONG ${ }^{1}$, WANG TIANQI ${ }^{1,3}$

${ }^{1}$ Institute of Mineral Resources, Chinese Academy of Geological Sciences, Beijing 100037, China

(wdong14@126.com, *correspondence: hylicags@126.com)

${ }^{2}$ School of Earth Sciences and Resources, China University of Geosciences, Beijing 100083, China

${ }^{3}$ Institute of Geology and Geophysics, Chinese Academy of Sciences, Beijing 100029, China

The Early Cretaceous mafic dikes exposed widely in Jiaodong Peninsula. These mafic dikes have been inffered to be derived from the enriched lithospheric mantle in the eastern part of the North China Craton, and have profound relationships with the regional-scale extension and the formation of gold deposits. The zircon U-Pb dating for the lamprophyres has been carried out to explore the evolution process and genesis mechanism of the enriched lithospheric mantle in Jiaodong Peninsula. These lamprophyres contain inherited zircons which may record multiple-thermal events of Jiaodong Peninsula and can provide significant clues for the late Mesozoic mantle dynamics beneath eastern North China Craton. Magmatic zircon age (c. 112Ma) shows that the lamprophyres were formed in Early Cretaceous. Some Inherited zircons with ages of Neoproterozoic and metamorphic zircons with Triassic ages indicate that the magmatic source should contain material from the Yangtze Block which had subducted beneath the North China Craton during the Triassic period. While other inhered zircons with Paleoproterozoic ages represent the fingerprints of the North China Craton. Therefore the enriched mantle source, from which these mafic dikes are derived, obviously encompassed the composition of the Yangtze Block and North China Craton. Combining with the Mesozoic tectonic evolution of Jiaodong Peninsula, it is possible to infer that the thickened crust which formed by the collision of North China Craton and Yangtze Block in the Mesozoic era was removed partly and delaminated into the mantle. These process triggered intense crust-mantle interaction and formed a new enriched lithospheric mantle beneath the Jiaodong Peninsula.

*This study is supported by the fund from the Ministry of Science and Technology of People's Republic of China (2016YFC0600105) and the National Natural Science Foundation of China (41673058, 4152098 and 41272090). 